Elsi Hyttinen

\title{
Samaan aikaan toisaalla. 1910-luvun siirtolaiskuvaukset toisin kuvittelemisen tilana
}

\begin{abstract}
Hän ei uskaltaisi ilmoittaakaan heille, että on nainut tavallisen piikatytön. [- - Voihan hän kertoa, että se on joku hieno nainen, joka on tullut tänne opiskelemaan ja he ovat menneet naimisiin. Mutta samassa tuli hänen mieleensä: kuka hieno nainen tulee Amerikkaan opiskelemaan kieltä? Hän puristi kätensä nyrkkiin, mutta huokasi sitten alistuvasti. (Ihmisiä, tästä eteenpäin I, 194.)
\end{abstract}

Näin tuskailee kovaa onneaan ylioppilas Reinhold Wikman novellissa, jonka kirjoitti toimittaja-kirjailija Kalle Tähtelä vuonna 1913. Ylioppilas on joutunut pinteeseen: hän on jo hyvän aikaa elellyt New Yorkissa piikojen rahoilla, ja nyt kaunein heistä, Eliina, on tullut raskaaksi. Wikman ei tiedä, mitä tehdä. Hän on työläisvanhempien kasvattama ensimmäisen polven ylioppilas ja ymmärtää, että menemällä naimisiin työläistytön kanssa hän romuttaisi vanhempiensa toiveet poikansa sosiaalisesta noususta. Kunniantunnon rippeet vaativat häntä kuitenkin huolehtimaan tytöstä. Mitä siis tehdä, kun valehtelu tytön syntyperästä ei ole vaihtoehto: kukaan Suomessa ei uskoisi, että Wikman on tavannut Amerikassa sivistyneen naisen. Sillä kuka hieno nainen Amerikkaan tulisi?

Tässä artikkelissa luen 1910-luvulla julkaistuja fiktiivisiä kuvauksia suomalaisista Amerikan-siirtolaisista. Kuvaukset ovat neljästä teoksesta: Matti Herneshuhdan Trämppejä (1911) ja Nestori Salmisen Muuttolinnut (1916) ovat romaaneja, Kalle Tähtelän Ihmisiä (1913) novellikokoelma ja Buster Brownin (Väinö Päiviön) Yli Atlannin (1915) alaotsikkonsa mukaan kokoelma "jutelmia", jo aiemmin lehdissä ilmestyneitä tilannekuvauksia. Teokset on julkaistu Suomessa lukuun ottamatta Trämppejä-romaania, jonka on kustantanut massachusettslainen Joel Björklund \& Co, ja Ihmisiä-kokoelmaa, joka julkaistiin samana vuonna sekä Suomessa että Yhdysvalloissa. Artikkelin keskeinen kysymys kirjoittautuu jo avaussitaattiin: Jos naiset eivät ole "hienoja", millaisia he sitten ovat? Entä miehet, millaisia heidän tuli olla? Millaisia ovat ne erityiset siirtolaisihmisenä olemisen tavat, joita näissä kirjoissa kuvataan?

1900-luvun alun suomenkielisen kirjallisuuden voi laajemminkin nähdä pyrkivän monimutkaistamaan sitä 1800-luvulta jäänteenomaisesti periytyvää nationalistista kehikkoa, jossa sallitun subjektiviteetin rajat määrittyivät perheen tarjoamien kehysten puitteissa. Perhe ymmärrettiin kansakunnaksi pienoiskoossa, ja tämä käsitys tuotti miehen ja naisen kaksinapaiseksi ymmärrettyä eroa: täysi kansalaisuus rakentui vasta perheen kautta, miehen ja naisen täydentäessä toisiaan. Tarkastelemissani Amerikansiirtolaisuuden kuvauksissa ihmiset on sen sijaan hyvässä ja pahassa heitetty selviyty- 
mään omillaan Atlantin toisella puolella, eikä nojaaminen komplementaariseen sukupuoli-ideologiaan ole heille tarjoutuvassa paikan, sukupuolen, liikkuvuuden ja elannon hankkimisen solmukohdassa kovinkaan mahdollista.

\section{Siirtolaiskuvaukset ja muutosten aika}

Artikkeli kysyy, kuinka 1900-luvun alun siirtolaiskirjallisuus kuvaa perhettä, siirtolaismiestä (trämppiä tai jätkää) ja siirtolaisnaista (kaupunkilaispiikaa), ja sen lähtökohdat ovat viimeaikaisissa keskusteluissa transnationaalisuudesta. Transnationaalisuuden käsitteellä on pyritty haastamaan humanistisiin ja yhteiskuntatieteisiin usein huomaamattomastikin piilottautuvaa sidosta nationalismiin (Pollari et al. 2015, 3-4; Wimmer \& Glick Schiller 2002). ${ }^{1}$

Transnationaalinen tutkimus korostaa kulttuuristen ja maantieteellisten rajojen vuotavuutta, ja sen lähtökohdista katsottuna paikalliskulttuurisiin kehyksiin nojaava tutkimus näyttää joskus jopa tutkimukselta kansallisissa umpioissa (Pollari et al. 2015, 5-6). Tässä artikkelissa pyrkimys transnationaalisuuteen tarkoittaa sitä, että en tulkitse siirtolaiskuvauksia ensisijaisesti 1900-luvun alun suomalaisamerikkalaisen siirtolaiskulttuurin tai identiteetin ilmentymiksi vaan luen niitä osana suomenkielisen kirjallisuuden kentällä tapahtuvaa merkityskamppailua, jossa hyödynnetään ylirajaisia hahmoja ja kertomisen tapoja.

Aineistoni tekstit on julkaistu joko Suomessa tai Yhdysvalloissa, yksi teoksista samana vuonna molemmissa maissa. 1900-luvun taitteessa julkaistujen Amerikansiirtolaisuuden kuvausten kenttää ei tietääkseni aiemmin ole systemaattisesti tarkasteltu kokonaisuutena vaan se on halkaistu kahtia, vaikkakin Raoul Palmgrenin (1966) tavan lukea siirtolaiskirjallisuus osaksi varhaisen työläiskirjallisuuden kenttää voi nähdä avaukseksi tähän suuntaan. Yhdysvalloissa julkaistuja kuvauksia on tarkasteltu siirtolaiselämän kuvauksina, joilla on ensisijaisesti etnografista arvoa, ja Suomessa julkaistut kuvaukset ovat ilman laajempia kytköksiään hukkuneet kansalliskirjallisuutemme ruohonjuurien sekaan. Lähtöhypoteesini on, että kun näitä suomenkielisiä siirtolaiskuvauksia niiden julkaisumaasta riippumatta luetaan suhteessa toisiinsa, piirtyy esiin jonkinlainen "toisaalla”, utooppinen tila, Atlantin takainen todellisuus, joka oli sekä hyvin todellinen että konstruktio. Se oli konstitutiivinen ulkopuoli, jota suomalaisuus väistämättä tarvitsi voidakseen kuvitella itseään.

Kysymyksen siirtolaiskuvausten funktiosta suomalaisuutta kuviteltaessa tekee tärkeäksi se, että ne on kirjoitettu Amerikan-siirtolaisuuden kiihkeimpinä vuosina tai heti niiden jälkeen: vuosien 1860 ja 1923 välillä noin 340000 suomalaista emigroitui Yhdysvaltoihin (Korkiasaari 1989, 8). Kiihkein liike asettuu välille 1899-1913, jolloin 10 000-20 000 suomalaista ylitti Atlantin vuosittain (Kero 1991, 25-26). ${ }^{2}$ Vuodet ovat samoja, joina Suomessa valtiolliset rakenteet kävivät läpi rajuja muutoksia: säätyvaltiopäivistä siirryttiin yleiseen ja yhtäläiseen äänioikeuteen 1906, ja yksitoista vuotta 
myöhemmin Suomi julistautui itsenäiseksi valtioksi. Yhdysvallat ja Atlantin yli muuttaminen ovat siten olleet jotakin hyvin ajateltavissa olevaa aikana, jolloin Suomessa yritettiin ratkaista, millaista poliittisesti itsenäinen suomalaisuus olisi. Tuolla toisaalla tapahtuvan elämän kuvittelulla on ehdottomasti etnografinen, siirtolaiselämän erityisyyttä taltioiva arvonsa, mutta väitän, että se palveli myös laajemmin aikalaistarvetta miettiä suomalaisuuden rajoja tilanteessa, jossa yhteiskunta modernisoitui ja monimutkaistui hyvää vauhtia.

1900-luvun alun Amerikan-siirtolaiskuvauksia ei ole tietääkseni juuri tarkasteltu näkökulmasta, jossa niiden ei nähdä heijastavan välittömästi kirjoitusympäristöään vaan jossa niiden katsottaisiin osallistuvan oikeanlaisen suomalaisuuden rajoista käytyyn symboliseen neuvotteluun. Arja Pilli (1986) ja Jaana Into (1996) ovat tutkineet Amerikan-siirtolaisten kirjallista kulttuuria institutionaalisesta näkökulmasta tarkastellen sitä nimenomaan siirtolaisyhteisön toimintana. Kiinnostavaa uutta tutkimusta siirtolaisten suullis-kirjallisista kulttuureista tekevät esimerkiksi Anne Heimo ja Kirsti Salmi-Niklander jälkimmäisen johtamassa tutkimusprojektissa Pirstaloituneet visiot (2014-2017) (fragvis.net). ${ }^{3}$

En väitä, että olisi väärin lukea kirjallisuutta syntykontekstinsa ristiriitojen heijastajana. Näiden tutkimusten asetelma on tarkan metodologisen harkinnan tulos ja liittyy siihen, millaista tietoa halutaan etsiä. Tarkoituksenani ei ole vaatia aikaisempaa tutkimusta tilille siitä, että se on sidoksissa toisenlaiseen paradigmaan kuin siihen, jota tässä artikkelissa vasta hahmotellaan. Sen sijaan korostan, että transnationaalinen keskustelu avaa siirtolaiskuvaukset aivan uudenlaiseksi aineistoksi, jonka avulla voi pohtia suomalaisuuden konstruoinnin dynamiikkaa.

Jos lykätään siirtolaiskuvausten selittämistä sillä, millaiseksi todellisuus niiden takana oletetaan, siirtolaiskuvaukset alkavatkin kertoa siitä neuvottelusta, jonka seurauksena tietyt luokan, sukupuolen ja kansalaisuuden kytkennät alkoivat näyttää toisenlaisilta kuin elämä "täällä". Siirtolaiskirjallisuus osallistuu tällöin kääntäen sen määrittelyyn, millaisia ovat ne normit, joista nämä kytkökset ovat poikkeuksia.

Suomalaisessa kirjallisuudessa mahdollisuus liikkua, oli kyse sitten taivaltamisesta tilassa tai noususta sosiaalisissa hierarkioissa, on usein luokkasidonnaista. Mitä korkeammalle luokkahierarkioissa hahmo sijoittuu, sitä suuremmat mahdollisuudet liikkua hänellä on. Tämä piirre on yhteneväinen niiden Pierre Bourdieun (1984; myös Skeggs 2004) luokkaa koskevien konstruktionististen teorioiden kanssa, joiden mukaan subjekti tuottuu luokkastatukseltaan sitä korkeammalle mitä enemmän hänelle kertyy erilaista yhteisössä vaihdon välineeksi kelpaavaa pääomaa. Siirtolaiskuvauksissa tämä on kuitenkin radikaalisti toisin: juuri omaisuuden ja aseman menetys on tekijä, joka saa esimerkiksi Kalle Tähtelän "Amerikkaan"-novellin Jannen ja Alviinan hakeutumaan Amerikkaan. Pääoman menettäminen pakottaa liikkuvuuteen. 


\section{Perheen ies}

Tässä artikkelissa käsitellyissä siirtolaiselämän kuvauksissa Atlantin takana ei juuri taloja rakenneta eikä perheitäkään perusteta. Pikemminkin epäonnistuminen heteroseksuaalisessa kansalaisprojektissa voi olla alkusysäys Amerikkaan lähtemiselle. Tällöin kyse on ennen kaikkea miehen epäonnistumisesta perheensä elättäjänä.

1800-luvun suomalainen kansallismielisyys tarvitsi perhettä. Perheessä jokaisella oli paikka: kaikki olivat perheenjäseniä. Perheen kautta yksilöt kytkettiin osaksi isompaa yhteiskuntarakennetta (Koivunen 1995, 241-242). Kansakuntaperhe oli voimakkaasti sukupuolittava rakenne: naiset toimivat yksityisen alueella ja kasvattivat lapsia, uusia kansalaisia. Mies taas oli perheen elättäjä, jonka tehtävä oli huolehtia perheyksikön taloudesta. (Häggman 1994, 136-141; myös Hyttinen 2012, 135-136.) Malli sisältää vain kaksi toimijan paikkaa, miehen tai naisen, ja olettaa nämä kaksi positiota toisiaan täydentäväksi (Koivunen 1995, 241). 1900-luvun alussa tätä mallia alettiin kritisoida niin päivälehdissä - elettiin julkisuuden murroskautta, ja uusia sanomalehtiä syntyi paljon - kuin kaunokirjallisuudessakin. Keskusteluihin nousivat esimerkiksi uuden naisen hahmot ja laajemminkin individualistiset ajatukset jokaisen ihmisen ainutkertaisuudesta ja täysivaltaisesta toimijuudesta, vaikka nämä ihanteet moneen kertaan osoitettiinkin vain vajavaisesti toteutuviksi luokka- ja sukupuolierojen maailmassa. Siirtolaiskuvaukset on mahdollista lukea yhdeksi julkisuuden ja maailman monimutkaistumisen ilmenemismuodoksi ja yhdeksi niistä kentistä, joilla etsittiin tapoja sanoutua irti kansakuntaperheestä ja kirjoittaa ihmisyydestä ilman, että se jäsentyisi perheen troopin tarjoamien roolien kautta.

Ihmisiä-kokoelman avausnovellissa Janne perii velkaisen talon. Talon edestä kuluvat sekä hänen että Alviina-vaimon voimat, mutta pellot eivät tuota satoa, metsät on myytävä ja silti velkojan saatavat ovat aina suuremmat kuin Jannen kokoon saamat varat. Alviina alkaa haaveilla lähdöstä Amerikkaan, mutta Janne on tiukkana: hän on perinyt talon isältään ja antanut tämän kuolinvuoteella lupauksen siitä, että hoitaisi sen myös. Lopulta molemmat ovat nääntymyksestä sairaita, ja talo huutokaupataan kuitenkin. Novellin loppukohtauksessa ollaan Hangossa satamalaiturilla. Siellä Jannen juttusille pyrkii hyvinvoiva isänmaanystävä:

Vieras katsahti heidän nyytteihinsä, istahti eräälle niistä ja rupesi juurta jaksain selittämään Jannelle, kuinka turmiollista oli, että reipas, maataviljelevä väestö menee maasta pois ja jättää autioiksi kauniit kanervikot ja laajat lahdelmat, siniset tuhatjärvet ja talven ihanat lumet.

Vieras innostui.

- Eikö ole synti ja häpeä, etteivät suomalaiset rakasta isänmaataan sen enempää, vaan menevät tekemään työtä vieraaseen maahan. Ja eikö meillä ole oma sivistyksemme ja oma luontomme, jonka vertaista ei muualla ole! Ettekö te tunne lainkaan isänmaanrakkautta? (I, 63-64.) 
Janne ei saa vastattua mitään, mutta lukija tietää: juuri maahan Janne tunsikin rakkautta, epätoivoista, järjen ylittävää rakkautta perimäänsä multaan, muttei silti onnistunut. Janne oli sisäistänyt samat ihanteet kuin laiturin hyvinvoiva puhuja, mutta epäonnistui niiden todeksi elämisessä. Lukija tietää, että satamalaituri on Jannen epäonnistumisen näyttämö. Siksi isänmaanystävän hahmo tuntuu alleviivaavan runebergiläisen kovan työn eetoksen ja toisaalta tuon kovan työn tekijöiden elämänkokemuksen välistä katkosta.

Sivistyneistön estetisoivan puheen ja maatyöväen todellisuuden rinnastaminen on tehokas ja paljon käytetty keino suomalaisessa 1900-luvun alun kirjallisuudessa (Melkas 2009, 116-117). Kirjallisuudentutkija Kukku Melkkaan mukaan kyse oli usein sivistyneistön itsekritiikistä. Siirtolaiskuvauksissa painotus on kuitenkin toisenlainen: kertoja ei liittoudu sivistyneen katseen kanssa tätä kohtausta pitemmäksi ajaksi eikä seuraa hänen mukanaan toisaalle pohtimaan massamaastamuuttoon johtaneen konjunktuurin ongelmia. Kertoja ei myöskään jää kertomiensa hahmojen kanssa Suomeen taistelemaan tämän estetisoivan katseen kanssa maailman selittämisen hegemoniasta. Sen sijaan hahmot ja heidän kertojansa lähtevät konkreettisesti muualle: seuraavissa novelleissa ollaan jo Amerikassa.

Janne ja Alviina lähtevät Amerikkaan nälän vuoksi ja siksi, että heidän tilansa on pakkomyyty. Abstraktimmalla tasolla voisi sanoa, että he lähtevät siksi, että Janne epäonnistui perheen elättäjyydessä ja sen seurauksena myös Alviina kansakuntaperhemallin hänelle tarjoamassa uusintajan roolissa. Kansakuntaperhe osoittautui rakenteeksi, joka hylki heitä: velkaisesta talosta ei riittänyt voimia sen performoimiseen oikein.

Myös Amerikkaan sijoittuvissa siirtolaiskuvauksissa, joita aineistostani on valtaosa, huonoimmin pärjäävät ne hahmot, joilla on perhe, mukana tai kotimaassa. Vanhan maailman sitoumukset ja uuden maailman todellisuus muodostavat ristiriidan, jonka kanssa on miltei mahdotonta elää. Kuitenkaan tätä ei aina nosteta juonen tasolla selvästi esiin. Ei ole kyse siitä, että kotimaassa oletukset olisivat vaikkapa erityisen epärealistiset sen suhteen, paljonko Amerikkaan lähtijän on mahdollista lähettää Suomeen rahaa. Pikemminkin ristiriita paikantuu tapaan, kuinka kirjalliset hahmot rakennetaan: perheeseen kiinnittyminen jollain tavalla merkitsee hahmon, ennustaa hänen tuhoaan. Tämä pätee esimerkiksi Tähtelän "Pelastettu”-novellin päähenkilöön Iisakki Kantolaan, joka kiertelee katuja köyhänä ja kuumeisena:

New Yorkiin saavuttuaan oli hän alkanut hakea työtä. Viisikymmentä dollaria, kaksisataa viisikymmentä markkaa, jotka hänellä oli ollut maihin noustessaan, oli kulunut ensimäisinä [sic] kuukausina ja hänen täytyi pyrkiä ruumiilliseen työhön. Kaksi viikkoa oli hän ollut kaivamassa katuja, kunnes hän sairastui. Vanha ruumis ei jaksanut kestää kylmää ulkotyötä. [- - ] Ne kaksi viikkoa olivat ainoat, mitkä hän oli tehnyt työtä tämän yhdeksän kuukauden ajalla, jotka hän oli ollut New Yorkissa. (I, 72-73.) 
Kantola ei kirjoita kotiin, vaikka ajattelee kotiaan koko ajan. "Hän ei tahtonut ilmaista vaimolleen kurjaa tilaansa ja jos hän olisi kirjoittanut, olisi hänen vaimonsa kirjeistä, rivien väleistä varmasti huomannut että hän oli joutunut rappiolle” (I, 73-74). Lopulta Kantola tuomitaan vankilaan, ja hän kiittää jumalaansa. Hänet on hetkeksi vapautettu taistelusta, jota hän ei osaa käydä. Nyt hänelle on tiedossa lämmin ruoka ja suoja viikoiksi eteenpäin.

Siveellinen perhemalli taas on koetuksella "Mrs Kulmala" -novellin newyorkilaiselämän kuvauksissa, joissa vaimot asettautuvat kunniallisuuden mittayksiköiden ulkopuolelle, nauramaan niille:

Täällä ei istuttu neule kädessä ja puhuttu taiteesta tai hyväntekeväisyydestä. Suomalaiset perheenäidit kokoontuivat täällä yhteen, miesten mentyä työhön, haettivat lapsilla olutta kotiin ja alkoivat pelata korttia. Kun vanhat juorut oli juoruttu, keksittiin uusia ja sitten taas naurettiin elämälle ja siveellisyydelle. (I, 218.)

Näissä katkelmissa perheen performoinnissa epäonnistutaan, perhe merkitsee siirtolaishahmon tuhoutuvaksi tai perheelle nauretaan. Useimmiten perhettä elämää jäsentävänä rakenteena ei edes kuvata, vaan siirtolaiskirjallisuuden hahmot ovat korostuneesti vain itsensä ja muodostamiensa sosiaalisten suhteiden varassa. Juuri perheen keskeisyys 1800-luvulta periytyvässä kansakunta-ajattelussa tekee sen puuttumisesta siirtolaiskuvauksissa merkittävä.̈. Aikana, jolloin parlamentaarisen järjestelmän uudistuminen pakotti kansalaisuuden ajattelemiseen ja omaksumiseen ihan uudella tavalla ja jona yhteiskunnan modernisoituminen vaati pohtimaan yksilön ja yhteisön suhdetta, siirtolaiskirjallisuus tarjosi pinnan, jolle heijastaa pelkoja ja toiveita siitä, millaista elämä hierarkkisen kansakuntaperheen tarjoaman kehyksen ulkopuolella voisi olla.

\section{Miesten kesken}

Heteroseksuaalista parisuhdeonnea käsitellään aineistossani oikeastaan vain Herneshuhdan Trämpeissä, ja siinäkin varsinaisesta tarinasta erillisessä jälkiluvussa. Itse romaani kuvaa kahden suomalaissyntyisen kulkurin matkoja pitkin avaraa länttä. Miehet ovat hyvin alttiita toistensa viehätysvoimalle ja hakevat toistensa hyväksyntää. Romaanin keskeinen jännite kulkee heidän välillään - kunnes lopussa tavataan kulkureista toinen, Vennu, seikkailujen jälkeen: ”[- - Hän sanoo olevansa jotensakin onnellinen, etupäässä siksi, että omistaa Fannyn. - Me siis kumpikin olemme päässeet osallisiksi tästä nykyajan poikkeustapauksesta: avio-onnesta.” (Trämpit, tästä eteenpäin T, 185.)

Ei riitä, että Vennu korostaa avio-onnen poikkeuksellisuutta nykyaikana: myös romaanin kertoja korostaa sitä. Vakuuttelua on niin paljon, että lukija miltei tulee epäluuloiseksi. 
Ja minulla on onni lopettaa tämä kirjani näin hauskoilla asioilla, siis poiketa aikamme useain realististen kirjailijain tavasta päättää kertomuksensa mahdollisimman synkästi - noudattaen aikamme ihmiselämän todellisuuden yleisempiä sääntöjä, joista nämä kauniit tapaukset ovat todellakin vain poikkeuksia. (T, 185-186, kursiivit kirjailijan.)

Vaikka siirtolaiskirjallisuuden miehet usein seikkailevat aavalla preerialla, mitään erityisiä westernin piirteitä aineistossani ei ole: intiaaneja ei kohdata, hevosilla ei ratsasteta, aseet eivät pauku - eivätkä edes saluunojen ovet. Pikemminkin Vennun ja Leon kaltaiset hahmot voisi nähdä versioina siitä jätkästä, jonka avulla suomalaisessa kirjallisuudessa usein käsitellään halua velvollisuuksien ja työn maailman ulkopuolelle (ks. Koivunen \& Laine 1993, 136). Trämpeissä maankiertäjät eivät ole yksilöitä, jotka uhmaisivat normeja alistuakseen niille lopulta, pikemminkin he ovat antisankareita, jotka aina lopulta palaavat normien ulkopuolelle. Romaanin lopun päälleliimattuus korostaa tätä: avioliitto ei sovita mitään syvempää ristiriitaa henkilöissä, vaan on jonkinlainen hassunkurinen käänne, joka veijareiden kohdalle on nyt sattunut. Utooppinen jätkämaskuliinisuuden alue ei kumoudu, vaikka romaani päätyy avio-onneen, koska "todellisuuden yleisempiä sääntöjä” tarkastellaan ironisen etäisyyden päästä.

Edellä esitin, että näissä siirtolaiskuvauksissa perhe on raskas rakenne, jonka oikein performoinnissa epäonnistuminen syöksee Amerikkaan tai tuhoon. Miestenväliset suhteet puolestaan ovat aineistossani usein sekä vapauden ehto että sen ilmentymä. Tämän kielellistää artikkelini avannut Reinhold Wikman, Reino, vuodatuksessaan, jossa samalla lukee omia vikojaan huijaamiensa naisten kannettaviksi:

- Ja sinä itse olet sen kaunis Adonis, - nauroi Törmäinen vuorostaan. - Kelpaahan sinun vaihtaa rooleja.

Reino tyhjensi lasinsa.

- Kelpaisi kyllä, jos naiset muuttuisivat miehiksi, mutta sitä he eivät tee.

Huh!.. - hän sylkäisi. - Näit toissakin iltana... Ooh, aivan inhoittaa. - Jos he maksaisivat ja olisivat tyytyväisiä siihen, että alennun seurustelemaan heidän kanssaan, mutta se ei heille riitä tietysti. He tahtovat valoja, velvollisuuksia, tunteellisuutta... äh, kaikkea he keksivätkin! He teeskentelevät antavansa lainaksi minulle, vaikka tietävät hyvin etteivät niitä ikinä takaisin saa. Heidän tekonsa on aivan samanlainen kuin jonkun pariisilaisen rikkaan, joka kustantaa naistensa ylläpidon, sillä erotuksella vaan, että minä saan asua kahden dollarin huoneessa ja syödä kapakoissa. He eivät tahdo tunnustaa itselleenkään että he ostavat minut, vaikka he sen selvästi näkevät. - - Sinäpä sen sanoit: "sellainen on naisen luonne". - Kun mies ostaa jotakin, maksaa hän rehellisesti, eikä anna rahoja lainan varjolla niin kuin naiset.

(I, 181-182.)

Vaikka Wikmanin ajatukset naisten ja miesten erilaisuudesta sosiaalisissa suhteissa ovatkin hänen oman tilanteensa värittämiä, hän myös tiivistää sanoissaan jotakin oleellista siirtolaiskuvausten maailmasta. Atlantin takaiseen maahan saapuvat miehet saattavat olla onnenonkijoita, ottaa vastaan työn yhtenä päivänä ja karata hommiaan hoitamatta 
seuraavana, varastaa tarpeeseen tai tilaisuuden tullen, tehdä syömävelkaa ja lupailla avioliittoa, mutta niin kauan kuin he ovat toisten miesten silmissä rehtejä kavereita, miesyhteisö kannattelee heitä. Usein miesten kuvataan tutustuvankin uuteen maailmaan liukumalla miesten muodostaman tukiverkoston varassa. Esimerkiksi Nestori Salmisen Muuttolinnut-romaanissa miesparivaljakko karkaa laivalta uudelle mantereelle ja tapaa vanhemman ja kokeneemman miehen, joka vihkii heidät oikeisiin tapoihin:

"Ovatko nuoret miehet vasta tulleet vanhasta maasta, kun ette näy tietävän, millä lailla oikea "hoopo" tässä maassa kulkee?"

"Olemme tulleet laivalla Etelä-Amerikan ympäri. - Palvelimme eräässä englantilaisessa laivassa, joka toi lastia Suomesta..."

"Ja tänne päästyänne karkasitte", lisäsi Apostoli nauraen.

"Oikein arvattu! Ja tänä yönä aiomme jo kävellä kappaleen matkaa tämän kaupungin ulkopuolelle."

"Ohoo, vai kävelemällä te...! Ei sitä säärivoimalla pitkälle potkita! Mutta jos haluatte liittyä Tramppi-Apostolin seuraan, niin minä näytän, kuinka matkaa tehdään, ja takaanpa, että tulette olemaan tyytyväisiä minuun."

(Muuttolinnut, 35.)

Mieskaverukset etsivät yhdessä työtä, toimeentuloa, sijaansa uudesta maasta - ja toki naisia. Naiset eivät kuitenkaan useinkaan ole etsinnän lopettava päämäärä, ja tämä on huomionarvoista. Miesparit saattavat etsiä naisten huomiota, mutta myös seuraavaa junaa, ansaintamahdollisuutta tai varastettavaa ruokapalaa. Olennaista on jaettu liike kohti kulloistakin tavoitetta. Tässä mielessä monien trämppikuvausten voisi nähdä noudattavan Eve Kosofsky Sedgwickin (1985) analysoimaa kolmiodraaman mallia. Sedgwick näkee, että kolmiodraama on yleinen englantilaisessa kirjallisuudessa hyödynnetty rakenne, jossa on kyse sukupuolesta ja vallasta. Sedgwick (1985, 21-24) esittää, että kolmiodraamassa kilpailijoiden välille rakentuva homososiaalinen suhde on yhtä tärkeä tai jopa tärkeämpi kuin kummankaan miehen suhde tavoittelun kohteeseen. Tällaisissa kertomuksissa heteroromanssin täydellistymisen kuvaus ei ole niin tärkeää, olennaisempaa on kuvata miesten välistä dynamiikkaa.

Homososiaalinen suhde voi olla eksplisiittisesti erotisoitunut tai se voi rakentua päinvastoin eroottisuuden mahdollisuuden kieltämiselle. Myöhemmille suomalaisen jätkyyden kuvauksille miestenvälinen halu on ollut hankala asia. Esimerkiksi tukkijätkäelokuvissa homoseksuaalinen halu johtaa sillä merkityn hahmon tuhoon (Koivunen \& Laine 1993, 139-140). Rillumarei-elokuvien buddy-yhteisö taas on turvallisen epäseksuaalinen (mt., 144). Herneshuhdan Trämppejä on kiinnostava tätä myöhempää homoseksuaalisuuden kieltämiselle perustuvaa jätkyyden mallia ajatellen, sillä Trämpeissä mies katsoo toista avoimesti haluten:

"Mutta yksinäsikö lähtisit?... En jää sinusta tänne, minne sitten lähtenemmekin. En perusta tästä paikasta ja sitäpaitsi ei sitä toverukset niin vain epämääräisen jälleen tapaamiseen nojaan eroa...”

Näin sanoessaan katseli Leo iloisesti Vennua silmiin, ja tämäkin ilostui. Mutta 
heidän ilollaan oli erilaiset syyt. Vennu iloitsi siitä, että sai taasen huomata omaavansa toverinsa täydellisen mieltymyksen: tuon toverinsa, jonka kunnioitusta ja mieltymystä hän oli alkanut oikein himoita, juurikuin sukupuolisesti rakastunut rakastettunsa lempeä. Leo taasen tunsi iloa siitä, että luuli saavansa sopivan syyn työpaikkansa hylkäämiseen [- - . (T, 67.)

On huomionarvoista, ettei tästä katseesta seuraa oikeastaan mitään. Kukaan ei tuhoudu, katsovaa hahmoa ei rankaista konkreettisesti eikä symbolisesti, mutta halua ei myöskään juonnellisteta tai ratkaista: tämä ei ole ulostulotarina muttei myöskään tarina väärän katseen stigmasta. Miestenvälinen sosiaalinen tila jossain Atlantin tuolla puolen on tila, jossa tuon katseen on mahdollista vain olla olemassa. Tämä on melkoisen voimakas utopia jopa tämän päivän näkökulmasta.

Siirtolaiskuvausten trämpit eivät ole kansakuntaperheen elättäjiä eivätkä kansalaistai muidenkaan velvollisuuksiensa toteuttajia. He elävät toverillisen vapauden tilassa, normien ulkopuolella. Heidät voi nähdä varhaisena varianttina niistä jätkähahmoista, joita myöhempikin kotimainen kirjallisuus on sijoittanut villiin luontoon. Elokuvatutkijat Anu Koivunen ja Kimmo Laine (1993, 149-150) ovat puhuneet tukkilaiselokuvien yhteydessä jälleenrakennuksen ajan varaventtiilistä, joka tarjosi mahdollisuuden nauttia velvollisuudestaan laistavien jätkien maailmasta. Samalla tavalla trämppikuvaukset 1900-luvun alun kirjallisuudessa tarjoavat turvallisen tilan, jossa kyseenalaistaa kansalaisuuden normeja. Turvallisen siksi, että mikään niissä kuvattu ei oikeastaan tapahdu "täällä" eikä koske suomalaisia. Kuvaukset kertovat niistä toisista, siellä.

\section{Vapaa nainen}

Aineistoni siirtolaispiiat varioivat kiinnostavalla tavalla sekä suomalaisen kirjallisuuden piikahahmoja että vapaan naisen kuvauksia. Siirtolaiskuvauksissa naisten vapaus ei ole teoreettinen ongelma, vaan siinä on kyse omasta rahasta ja kaupunkitilasta, jossa liikkua. Tällä vapaudella on aivan tiettyjä ulkoisia tunnusmerkkejä, kuten käy ilmi Sannin kuvauksesta Buster Brownin (Väinö Päiviö) novellissa "Mallassaunalla”:

Mutta aika kului, joskin hitaasti, ja vähitellen kotoiset kuvat katosivat. Sanni alkoi muuttua yhä enemmän amerikalaiseksi: kannat kengissä kohosivat, tukka sai uuden, uhkaavan asennon, koko ryhti muuttui, että tuskin samaksi Sanniksi tunsi. (Yli Atlannin, 65.)

Tässä kovalla työllä itsensä elättävässä ja kaupunkitilassa itsenäisesti liikkuvassa naisessa sekä on että ei ole kyse 1900-luvun alun uuden naisen figuurista, jonka avulla aikalaiskirjallisuus pohti toimijuuden ja sukupuolen sekä modernisaation aiheuttamien yhteiskunnallisten muutosten kysymyksiä. Ensinnäkin uuden naisen figuuri oli verrattain keskiluokkainen (Parente-Čapková 2005, 150; Rojola 1999, 161; Ledger 1997, 16, 35-36). Lisäksi suomalaisessa kirjallisuudessa uusi nainen pohti 
usein nietzscheläisin sanakääntein vapauden ja yksilöyden rajoja, kun taas näillä piikahahmoilla ei välttämättä ole lainkaan sanoja omalle emansipaatiokehitykselleen. Uuden naisen projekti oli usein epäonnistuva: vaikka hahmo asetti kysymyksen naisen vapaudesta ja naiselle sallitusta sosiaalisesta ja fyysisestäkin tilasta, sen kautta piirtyi usein ennen kaikkea näkyviin tuon tilan ahtaus. Niinpä esimerkiksi Elvira Willmanin Rakkauden orjuus -näytelmässä itsenäistä elämää tavoitteleva taiteilija joutuu alistumaan vaimoksi, kun elämä yksinhuoltajana osoittautuu umpikujaksi (Hyttinen 2015) ja L. Onervan tuotannossa erityisesti työläisnaiset joutuvat luopumaan uhmastaan (Parente-Čapková 2005, 152-153).

Amerikassa sen sijaan piioillakin on vapautta ja omaa tilaa, kuten Suomessa käyminen saa Mantan tajuamaan Tähtelän novellissa "Manta ja Matti”: ”[- - ] hän ajatteli jo kuinka New Yorkissa aika lensi kuin siivillä päivästä toiseen. Täällä ei ollut paikkaa mihin mennä huvittelemaan, ei edes tanssiaisia." (I, 263.) Suomalaisissa piikakuvauksissa itsenäistymis- ja kohoamispyrkimysten palkka on usein sosiaalinen romahdus (Melkas 2009, 120-122): prostituutio, alkoholismi tai kuolema. Siirtolaiskuvauksissa palkkana saattavat olla paremmat olot.

[- -] eikä hän [Manta] uskaltanut ajatellakaan ryhtyä entisiin töihin, entiseen raadantaan. Hän oli Amerikassa ollessaan saanut enemmän vapautta ja lopulta helpompaa työtäkin ja hyvää palkkaa, ja hän kauhistui niitä aikoja, jolloin hänen oli kotona täytynyt kärsiä nälkää. (I, 267.)

Siirtolaisyhteisö Atlantin takana on paikka, jonne työväenluokkaisen vapaan naisen saattoi sijoittaa ilman, että se uhkasi suomalaista kansallista järjestystä. Tuo vapaus oli korosteisesti paikkaan sidottua, mahdollista vain siellä toisaalla. Sen merkitsijät vaatteet, kampaukset, vapaa-ajanviettotavat - viestivät vapaudesta vain Amerikassa. Suomessa niiden viesti muuttuu tyystin toisenlaiseksi ja ne uhkaavat tehdä kantajansa naurunalaiseksi. Tämän ymmärtää vähitellen Matti, joka osaa lukea sekä rakastettunsa Mantan amerikkalaisia signaaleja että suomalaisyhteisön ynseyttä:

Hän oli pannut jo ennen merkille, ettei Manta tahtonut heittää kaupunkivaatteitaan päältään, vaikka oli huomannut, etteivät ne sopineet täällä, ja vaikka ihmisetkin jo kylällä ihan ihmeenä kertoivat, että Manta pitää yhä päällään hienouksiaan ja makaa puolille päivin. Matista oli joskus näyttänyt kuin olisi Manta aivan uhalla niitä pitänyt. (I, 264-265.)

Omaa rahaa ja tilaa saavuttanut nainen ei halua niistä luopua, ja niinpä Suomeen paluuta yrittäneet Matti ja Manta tekevät sopuratkaisun. Matti jää, Manta lähtee:

Nyt ei kuitenkaan ollut ikävä erotessa. Mantaa säälitti hiukan Matti, joka ehdoin tahdoin jäi korpeen hallan ja nälän uhriksi, mutta oli mielissään, että pääsi itse pois ihmisten joukkoon, ja Matti puolestaan toivoi, ettei Manta pahasti kohliutuisi [sic] siellä maailman jaloissa. (I, 277.) 
Ei naisten vapautta kuitenkaan mitenkään yksiselitteisen ihannoivasti kuvata. Siirtolaiskuvauksissa toistuvat myös naisilta rahat vievät huijarit, alkoholi, masennus, yksinäisyys ja puoskaroidut abortit. Näidenkään vaihtoehto ei kuitenkaan välttämättä ole paluu Suomeen, vaan karussa maailmassa voi oppia myös elämään. Elvi Kulmala kohoaa kätilön koulutuksensa avulla kysytyksi raskaudenkeskeyttäjäksi, jolla on rahaa, miehiä ja kiihkeä elämä:

Hän näki nyt selvästi niinkuin muutkin, ettei hänellä ollut enää odotettavissa sitä elämää, josta hän oli uneksinut, ja jos hän tahtoi elää ja nauttia, oli hänen tehtävä niin kuin muidenkin, käytettävä hyväkseen kaikki ilon lähteet, hyvät ja huonot. Hän katkeroitui siitä huomiosta, mutta eli kuitenkin. Se oli suurkaupungin laidassa, köyhien talojen asukasten elämänviisautta, ja se tuli Elvin pelastajaksi nyt, niin kuin se oli tullut niin monen muun pelastajaksi sitä ennen. (I, 219.)

Tämä "Mrs Kulmala" -nimisen novellin päähenkilö tuhoutuu tarinansa lopussa, ja on sitä kautta yhteydessä moniin muihin maailman kirjallisuuden naisiin, jotka ylittävät säädyllisyyden rajat (DuPlessis 1985, 1-5). Kulmala elää hänkin erilaisten arvojärjestelmien ristipaineessa. Hän alkaa nähdä lähdettämiensä sikiöiden aaveita kaikkialla, ja lopulta hänen mielensä hajoaa.

Sietämätöntä vapaudessa saattaa olla myös yksinäisyys. Justiina, Tähtelän samannimisen novellin päähenkilö, on vuodesta toiseen ajatellut, että vielä kerran hän palaa ja pelastaa äitinsä. Ajatus äidistä, jonkinlainen hyväksyvän ja kaipaavan äidinkatseen projektio, on tehnyt Amerikassa olon mielekkääksi. Kun uutinen äidin kuolemasta tulee, kaikelta katoaa pohja.

Äitikin kuollut. -- Mitä hän täällä teki? Eihän hänellä enää ollut mitään täällä tehtävää. Ei mitään, kaikki oli tyhjää ilmaa. Hänkin oli hyödytön olento täällä. Ketä varten hän oli? Ei ketään. - Itseäänkö varten? Hän ei itsekään ollut enää mikään. Minne hän vaan katselikin -- kaikkialla oli tyhjää -. Eikä ketään maailmassa, ei, ei mitään --. (I, 156.)

On kiinnostavaa, että näitä maailmankirjallisuuden peruskysymyksiä vapaudesta, vallasta ja ihmisen osasta kysytään 1900-luvun alun siirtolaiskuvauksissa työväenluokkaisen naisen hahmon kautta. Taloudellinen itsenäisyys ja se, että he ovat jo jättäneet kasvuympäristönsä taakseen, tekee näistä naisista jo lähtökohtaisesti yksilöitä eksistentiaalisessa mielessä: hyvässä ja pahassa he vastaavat itsestään. Heidän vapautensa ei ole päämäärä jossain tulevaisuudessa vaan jotain jo toteutuvaa, eikä sitä piirretä esiin niinkään suhteessa mieheen kuin suhteessa tapoihin, joilla he itse ovat maailmassa: heidän ulkonäköönsä, mieltymyksiinsä, mahdollisuuksiinsa liikkua kaupunkitilassa, kykyyn pelata sosiaalisia pelejä ja hallita ajankäyttöän. 


\section{Lopuksi}

Näinä aikoina Euroopassa on enemmän pakolaisia kuin koskaan toisen maailmansodan jälkeen. Oikeistopopulismi kerää kovaäänisiä kannattajajoukkoja ja kaikenlaisia argumentteja eurooppalaisten kansojen luonnollisesta oikeudesta vaurauteensa ja territorioihinsa esitetään. Siksi on tärkeää kysyä, missä määrin siirtolaisuus kulttuurisena resurssina, mahdollisuutena ajatella lähtöä ja kuvitella jonkinlainen "toisaalla" - maantieteellisesti kaukana oleva alue, jonkinlainen utooppinen tila, jossa ihmisiä määrittäisivät toisenlaiset sitoumukset ja säännöt kuin kotimaassa - vaikutti ja osallistui suomalaisuudenkin konstruointiin 1900-luvun alun poliittisesti kiihkeinä vuosina. Tässä artikkelissa olen neljän kaunokirjallisen teoksen tarjoaman, varsin rajallisen aineiston kautta pyrkinyt osoittamaan, kuinka mielenkiintoista 1900-luvun alun siirtolaiskirjallisuus suomalaisuuden rakentumisen näkökulmasta on. Aineistoni kirjoittamisen aikaan Suomessa elettiin monenlaisten, päällekkäisten kriisien aikaa. Kaikki saivat nyt äänestää, mutta se, mitä kansalaisuus tarkoitti, oli vasta muotoutumassa. Kaupungit kasvoivat, teollistuminen kiihtyi, luokkaerot kärjistyivät. Samalla elettiin toista sortokautta. Siirtolaiskirjallisuus tarjosi tilan ja mahdollisuuden erilaisten toiveiden, fantasioiden ja vaihtoehtoisten todellisuuksien kuvittelemiselle.

Siirtolaiskirjallisuuden luonne suomalaisuuden kuvittelun utooppisena "varaventtiilinä" (vrt. Koivunen \& Laine 1993, 149-151) piirtyy esiin, kun kuvauksia ei selitetä ensisijaisesti sillä miljööllä, jota ne kuvaavat. Aiempi tutkimus on ollut pitkälti kiinnostunut siirtolaiskirjallisuuden etnografisista ulottuvuuksista, siitä, mihin mittaan ne heijastavat todellisten siirtolaisyhteisöjen tapoja ja sen jäsenten elämänkohtaloita. Tässä artikkelissa lähtökohtanani on ollut transnationalistisessa hengessä irrottaa kuvaukset tästä vahvasta tulkintakehikosta ja katsoa niitä kirjallisuutena, joka varioi samoja trooppeja kuin aikansa muukin kirjallisuus, ei niinkään rakennu suhteessa jonkin tietyn territorion elämänmalliin. Nostin esiin erityisesti siirtolaiskuvausten hankalan suhteen perheeseen, miestenkeskiset sosiaaliset verkostot ja työväenluokkaiset naisyksilöt.

Artikkelia kannattelee ajatus siitä, että siirtolaisuuden kuvaaminen oli samalla neuvottelua suomalaisuuden rajoista. Aineistoni on riittävän suuri hypoteesini alustavaan esittämiseen. Sen pitävämpi todentaminen vaatisi kuitenkin laajemman aineiston ja jatkotutkimusta. Olisi kiinnostavaa suhteuttaa toisiinsa perusteellisemmin siirtolaisfiktiossa konstruoituvaa utooppista "toisaalla"-tilaa ja Suomessa eletyksi kuvatun suomalaisuuden "täällä"-tilaa. ${ }^{4}$ Lisäksi transnationalismin hengessä näitä tiloja pitäisi lukea horisontaalisesti suhteessa toisiin siirtolaiskirjallisuuksiin, vaikkapa siihen, kuinka italialaisen tai irlantilaisen kirjallisuuden kentällä Amerikkaan-lähtijät merkityksellistyvät. Toisaalta olisi ylitettävä kansallisten kontekstien rajat ja jäljitettävä niiden siteerausten ja lainausten ylirajaisia ketjuja, joiden tuloksia tässäkin analysoidut jätkän, piian ja perheen troopit ovat. 


\section{Viitteet}

${ }^{1}$ Suomalaisen kirjallisuuden tutkimukseen transnationaalisuuden käsitteen on tuonut ennen kaikkea Olli Löytyn johtama tutkimusprojekti Suomalaisen kirjallisen kulttuurin ylirajaisuus (2012-2013) (ylirajainenkirjallisuus.wordpress.com ). Projektin tutkijat Ralf Kauranen ja Mikko Pollari ovat ensimmäisten joukossa soveltaneet transnationaalisuuden käsitettä suomalaisen Amerikan-siirtolaisuuden tutkimukseen artikkelissaan, joka käsittelee 1900-luvun alun suomalaisia ja amerikansuomalaisia sosialisteja (Kauranen \& Pollari 2011).

${ }^{2}$ Vasta ensimmäinen maailmansota pysäytti tämän liikkeen. 1920-luvulla muuttoliike piristyi hetkeksi uudelleen, kunnes vuonna 1924 Yhdysvaltain hallitus alkoi kontrolloida ja rajoittaa sitä rajusti: enää 471 suomalaista sai tuona vuonna maahanmuuttoluvan (Korkiasaari 1989, 24).

${ }^{3}$ Myös muualle suuntautuvan siirtolaisuuden kirjallisten kuvausten tutkimuksessa siirtolaiselämä erityispiirteineen on olennaisesti se pohjarakenne, jota kirjallisuuden nähdään heijastavan. Erkki Valleniuksen Ruotsiin muuttaneita suomalaisia kaunokirjallisuudessa käsittelevän tutkimuksen Kansankodin kuokkavieraat fokus on akkulturaatiossa, siirtolaiselämän aiheuttamassa ristiriidassa ja yksilön yrityksissä ratkaista niitä (Vallenius 1998, 23). Kulttuurisen identiteetin työstämisenä siirtolaiskirjallisuutta lähestyy myös esimerkiksi Marja-Liisa Punta-Saastamoinen (2010) australiansuomalaista kirjallisuutta käsittelevässä tutkimuksessaan Australiansuomalaiset etsivät itseään.

${ }^{4}$ Artikkelin työstämisen loppuvaiheessa olen saanut tietää, että Suomen Kulttuurirahasto on myöntänyt minulle apurahan laajempaan, juuri näitä kysymyksiä pohtivaan tutkimusprojektiin "1900-luvun alun Amerikan-siirtolaisuudenkuvaukset osana suomalaisen kirjallisuuden kenttää".

\section{Kirjallisuus}

Bourdieu, Pierre 1984. Distinction: a Social Critique of the Judgement of Taste. Trans. Richard Nice. London: Routledge \& Kegan Paul.

Buster Brown [Väinö Päiviö] 1915. Yli Atlannin. Siirtolaisjassen jutelmia. Helsinki: V. Kososen kustannusliike O. Y.

DuPlessis, Rachel Blau 1985. Writing Beyond the Ending. Narrative Strategies of Twentieth-Century Women Writers. Bloomington: Indiana UP.

Herneshuhta, Matti 1911. Trämppejä. Romaani [= T]. Worcester, Massachusettes: Joel Björklund \& Co. Kustannuksella.

Hyttinen, Elsi 2012. Kovaa työtä ja kohtalon oikkuja. Elvira Willmanin kamppailu työläiskirjallisuuden tekijyydestä vuosisadanvaihteen Suomessa. Turku: Annales Universitatis Turkuensis.

Hyttinen, Elsi 2015. Women in Early Capitalism and Other Irrelevant Issues: Elvira Willman's Struggle for Working-Class Authorship. Journal of Finnish Studies vol 18 no 2, 56-74.

Häggman, Kai 1994. Perheen vuosisata. Helsinki: SHS. 
Into, Jaana 1996. Vaik mä lennän lehden lailla. Amerikansuomalaisen kirjallisuusinstituution ja kaunokirjallisuuden kehitys "suuren siirtolaisuuden" aikana. Pro Gradu, Joensuun yliopisto.

Kauranen, Ralf \& Mikko Pollari 2011. Transnational Socialist Imagination. The Connections between Finnish Socialists in the USA and Finland at the Turn of the 20th Century. Michel S. Beaulieu, Ronald N. Harpelle \& Jaimi Penney (eds.), Labouring Finns. Transnational Politics in Finland, Canada, and the United States. Turku: Siirtolaisinstituutti, 26-49.

Kero, Reino 1991. Suomen siirtolaisuuden historia 1. [3. painos.] Turku: Turun yliopisto.

Korkiasaari, Jouni 1989. Suomalaiset maailmalla. Suomen siirtolaisuus ja ulkosuomalaiset entisajoista tähän päivään. Turku: Siirtolaisinstituutti.

Koivunen, Anu 1995. Isänmaan moninaiset äidinkasvot. Turku: Suomen elokuvatutkimuksen seura.

Koivunen, Anu \&, Kimmo Laine 1993. Metsästä pellon kautta kaupunkiin (ja takaisin). - Jätkyys suomalaisessa elokuvassa. Pirjo Ahokas, Martti Lahti ja Jukka Sihvonen (toim.), Mieheyden tiellä. Maskuliinisuus ja kulttuuri. Jyväskylä: Nykykulttuurin tutkimusyksikön julkaisuja, Jyväskylän yliopisto, 136-154.

Ledger, Sally 1997. The New Woman. Fiction and Feminism at the Fin de Siècle. Manchester: Manchester UP.

Melkas, Kukku 2005: Toisen palveluksessa. Palvelijat porvarillisen perheen ja työväenluokan välissä. Olli Löytty (toim.), Rajanylityksiä. Tutkimusreittejä toiseuden tuolle puolen. Helsinki: Gaudeamus, 162-180.

Melkas, Kukku 2009. Palvelustyttö sivistyneistön peilinä. Kukku Melkas, Heidi Grönstrand, Kati Launis, Maarit Leskelä-Kurki, Jussi Ojajärvi, Tutta Palin \& Lea Rojola (toim.), Läpikulkuihmisiä. Muotoiluja kansallisuudesta ja sivistyksestä 1900-luvun alun Suomessa. Helsinki: SKS, 107-134.

Palmgren, Raoul 1966. Joukkosydän I-II. Vanhan työväenliikkeemme kaunokirjallisuus. Helsinki: WSOY.

Parente-Čapková, Viola 2005. Nainen, kenen toinen? 1900-luvun alun uusi nainen sukupuolirajojen rikkojana. Olli Löytty (toim.), Rajanylityksiä. Tutkimusreittejä toiseuden tuolle puolen. Helsinki: Gaudeamus, 142-161.

Pilli, Arja 1986. Tendenssiromaaneja, surullista romantiikkaa ja opaskirjasia : siirtolaisten kirjallisuudesta ja julkaisutoiminnasta. Keijo Virtanen, Arja Pilli \& Auvo Koistinen (toim.), Suomen siirtolaisuuden historia 3. Turku: Turun yliopisto, 123-144. 
Pollari, Mikko, Hanna-Leena Nissilä, Kukku Melkas, Olli Löytty, Ralf Kauranen \& Heidi Grönstrand 2015. National, Transnational and Entangled Literatures: Methodological Considerations Focusing on the Case of Finland. Ann-Sofie Lönngren, Heidi Grönstrand, Dag Heede \& Anne Heith (eds.), Rethinking National Literatures and the Literary Canon in Scandinavia. Cambridge: Cambridge Scholars Publishing, 2-29.

Punta-Saastamoinen, Maija-Liisa 2010. Australiansuomalaiset etsivät itseään. Kulttuurisen identiteetin määrittyminen australiansuomalaisessa kirjallisundessa. Turku: Siirtolaisinstituutti.

Rojola, Lea 1999. Modernia minuutta rakentamassa. Teoksessa Lea Rojola (toim.), Suomen kirjallisuushistoria 2. Järkiuskosta vaistojen kapinaan. Helsinki: SKS, 150164.

Rojola, Lea 2009. Sivistyksen ihanuus ja kurjuus - suomalaisen nousukkaan tarina. Kukku Melkas, Heidi Grönstrand, Kati Launis, Maarit Leskelä-Kurki, Jussi Ojajärvi, Tutta Palin \& Lea Rojola (toim.), Läpikulkuibmisiä. Muotoiluja kansallisuudesta ja sivistyksestä 1900-luvun alun Suomessa. Helsinki: SKS, 10-38.

Salminen, Nestori 1916. Muuttolinnut. Kuvaus Amerikan suomalaisten siirtolaiselämästä. Lahti: Aug. Kanervan kirjapaino.

Skeggs, Beverley 2004. Class, Self, Culture. London \& New York: Routledge.

Tähtelä, Kalle 1913. Ihmisiä. Siirtolaisnovelleja [= I]. Helsinki: Kustannusosakeyhtiö Kirja.

Vallenius, Erkki 1998. Kansankodin kuokkavieraat. II maailmansodan jälkeen Ruotsiin muuttaneet suomalaiset kaunokirjallisunden kuvaamina. Helsinki: SKS.

Wimmer, Andreas \& Nina Glick Schiller 2002. Methodological nationalism and beyond: nation-state building, migration and the social sciences. Global Networks 2/2002, 301-334. 